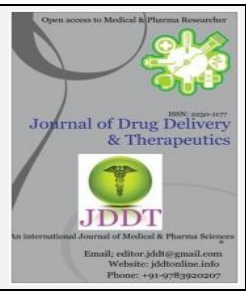

Open $\odot$ Access

Research Article

\title{
Formulation and Characterization of Aceclofenac Mouth Dissolving Tablet by QbD
}

\author{
Dev Asish*1, Yadav Shravan Kumar ${ }^{2}$, Kar S.K. ${ }^{3}$, Mohanty Smitapadma ${ }^{4}$, Shelke Om ${ }^{5}$ \\ 1, 2, 3 Department of Pharmaceutics, Oriental College of Pharmacy, Sanpada, University of Mumbai \\ 4 School of Pharmaceutical Science and Research, Berhampur University, Odisha, \\ 5 Institute of Pharmacy, Pacific University, Udaipur, Rajasthan
}

\begin{abstract}
The purpose of this study was to develop fast dissolving tablets of Aceclofenac using different concentration of super disintegrants. Fast dissolving tablets of Aceclofenac were prepared by dry granulation technique using croscarmellose sodium together with avicel ph as superdisintegrants. The porous granules were then compressed in to tablets by direct compression technique. These tablets were evaluated for drug content, weight variation, friability, hardness, wetting time and dispersion time. All the formulations showed low weight variation with dispersion time less than 90 seconds and rapid in vitro dissolution. The drug content of all the formulations was within the acceptable limits The optimized formulation showed good release profile i.e. maximum drug being released at all-time intervals compared to other trial batches. It was concluded that fast dissolving tablets with improved dissolution could be prepared by dry granulation method of tablet.
\end{abstract}

Keywords: Aceclofenac, fast dissolving tablet, dry granulation, super disintegrants.

Article Info: Received 12 June 2019; $\quad$ Review Completed 19 July 2019; $\quad$ Accepted 25 July 2019; Available online 15 Sep 2019

\section{Cite this article as:}

Dev A, Yadav SK, Kar SK, Mohanty S, Shelke O, Formulation and Characterization of Aceclofenac Mouth Dissolving Tablet by QbD, Journal of Drug Delivery and Therapeutics. 2019; 9(5):43-50 http://dx.doi.org/10.22270/jddt.v9i5.3538

*Address for Correspondence:

Dev Asish, Department of Pharmaceutics, Oriental College of Pharmacy, Sanpada, University of Mumbai

\section{INTRODUCTION}

Oral drug delivery is the most advisable route for drug administration among all the routes used for drug delivery. Various types of dosage forms are prepared for administration of drug via oral route. Solid dosage forms are popular because of ease of administration, self medication, accurate dosage, pain avoidance and most importantly the patient compliance.[1] Dysphagia occurs in children due to undeveloped muscular and nervous system, geriatric patients suffering from Parkinson's disease, bedridden \&mentally ill patients. [2]

To overcome these problems mouth dissolving tablets are the best choice of formulation. These tablets get disintegrated or dissolved in buccal cavity avoiding water consumption. This is a newer dosage form that gets dissolved in saliva in very few seconds. these tablets are also known as melt in mouth tablet (MMT), Fast melting tablet (FMT), Fast dissolving tablet (FDT), Orally Disintegrated tablet (ODT), Rapidly Disintegrated tablet (RDT).[3]

Aceclofenac,(2-[2-[2-(2,6- dichlorophenyl)aminophenyl] acetyl]oxyacetic acid), a nonsteroidal anti-inflammatory drug NSAID) has been indicated for various painful indications and proved as effective as other NSAIDs with lower indications of gastro-intestinal adverse effects and thus, result in a greater compliance with treatment[4].

Aceclofenac is practically insoluble. For poorly soluble orally administered drugs, the rate of absorption is often controlled by the rate of dissolution. [5] In the present study, an attempt was made to develop mouth dissolving tablets of aceclofenac and to investigate the effect of different concentration of super disintegrants on the release profile of the drug by using $3^{2}$ factorial design in design expert software.

\section{MATERIALS AND METHODS}

\section{Materials}

Aceclofenac was gifted by medley pharmaceuticals, croscarmellose sodium and avicel ph were gifted by signet chemical Mumbai. Lactose, sodium saccharine, magnesium stearate were purchased from S.D Fine Chem. Mumbai. 


\section{Method used}

Mouth dissolving tablets of Aceclofenac were prepared by using two super disintegrants croscarmellose sodium and avicel ph, lactose as diluent, sodium saccharin as sweetening agent and magnesium stearate as a flow promoter.

\section{Blending and tableting}

Tablets containing $250 \mathrm{mg}$ of Aceclofenac are prepared by dry granulation method and various ingredients used in the study are shown in Table 1. The drug, diluents, super disintegrants and sweetener are passed through sieve \# 40 and then passed through sieve \#20. All the above ingredients were properly mixed to obtain coherent mass. The powder blend was compressed in to tablets on twelve station rotary punch-tableting machine (Karnavati, Rimek Mini Press- 2) using $8 \mathrm{~mm}$ concave punches set. The hardness of tablets was taken between 3 and $4.5 \mathrm{~kg} / \mathrm{cm}^{2}$.

Table 1: Formulation Table

\begin{tabular}{|c|c|c|c|c|c|c|c|c|c|c|}
\hline S.N. & INGREDIENTS & F1 & F2 & F3 & F4 & F5 & F6 & F7 & F8 & F9 \\
\hline $\mathbf{1}$ & Aceclofenac & 100 & 100 & 100 & 100 & 100 & 100 & 100 & 100 & 100 \\
\hline $\mathbf{2}$ & Cross Carmellose Sodium & 12.5 & 10 & 7.5 & 12.5 & 10 & 7.5 & 12.5 & 10 & 7.5 \\
\hline $\mathbf{3}$ & Sodium Saccharin & 2 & 2 & 2 & 2 & 2 & 2 & 2 & 2 & 2 \\
\hline $\mathbf{4}$ & Micro Crystalline Cellulose & 35 & 35 & 35 & 30 & 30 & 30 & 25 & 25 & 25 \\
\hline $\mathbf{5}$ & Mg Stearate & 12.5 & 12.5 & 12.5 & 12.5 & 12.5 & 12.5 & 12.5 & 12.5 & 12.5 \\
\hline $\mathbf{6}$ & Lactose & 86 & 88.5 & 91 & 91 & 93.5 & 96 & 96 & 98.5 & 101 \\
\hline
\end{tabular}

\section{RESULTS AND DISCUSSION}

\section{Authentication of Drug:}

a. UV Spectrophotometry:The solution of aceclofenac in PBS (pH 7.4) was found to exhibit maximum absorption ( $\lambda$ max) at 276 $\mathrm{nm}$ after scanning in the range of $200-400 \mathrm{~nm}$ by UV spectrophotometer.

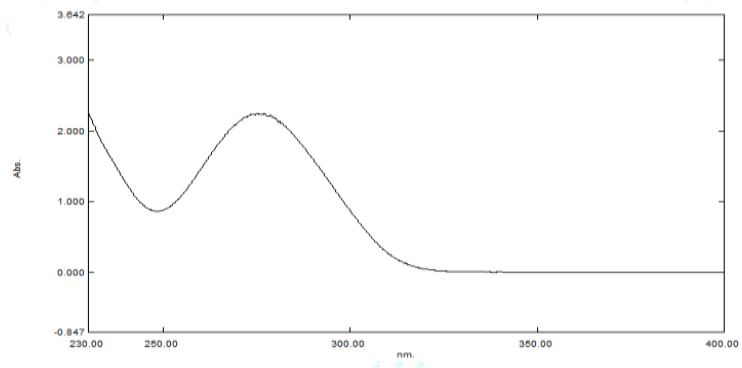

Fig 1: UV spectrum of Aceclofenac

b. Fourier transmission infrared (FT-IR) spectroscopy: Identity of the drug was confirmed by comparing IR spectrum of drug with reported spectrum of Aceclofenac as shown in Fig.

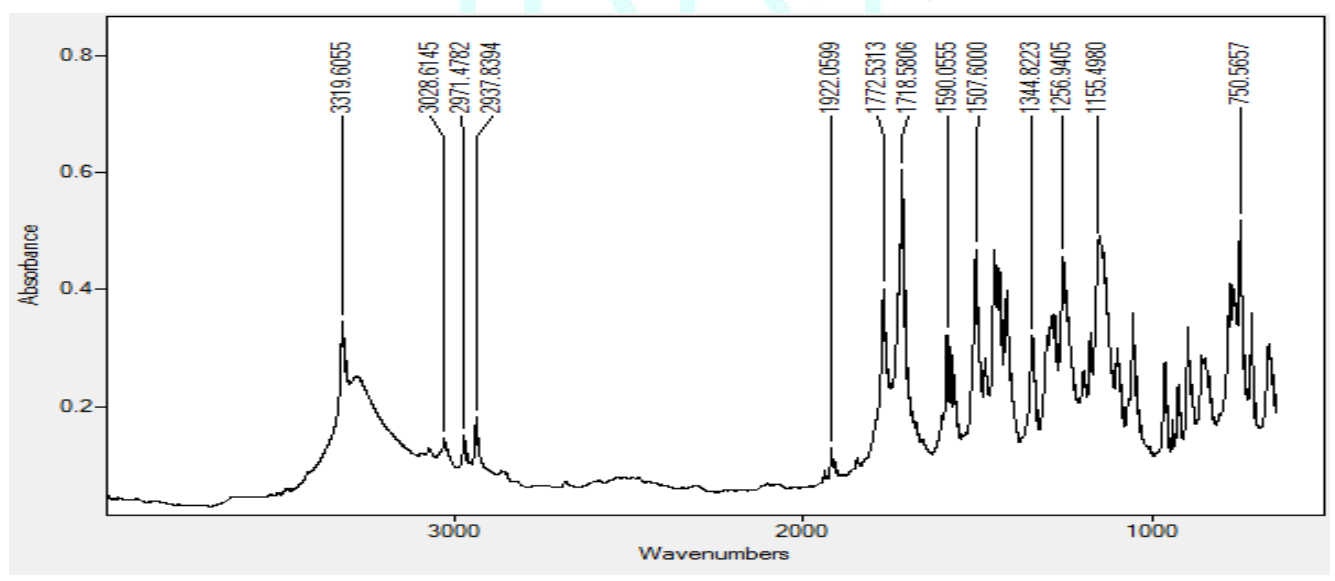

Fig 2: FT-IR spectrum of Aceclofenac

Table 2: IR Frequency range

\begin{tabular}{|c|c|}
\hline Functional groups & Ranges \\
\hline C-C streching bond & 1772 \\
\hline C=O bond & 1718 \\
\hline C=C bond & 1589 \\
\hline -COOH bond & 1590 \\
\hline -NH bond & 1507 \\
\hline C-Cl bond & 748 \\
\hline
\end{tabular}




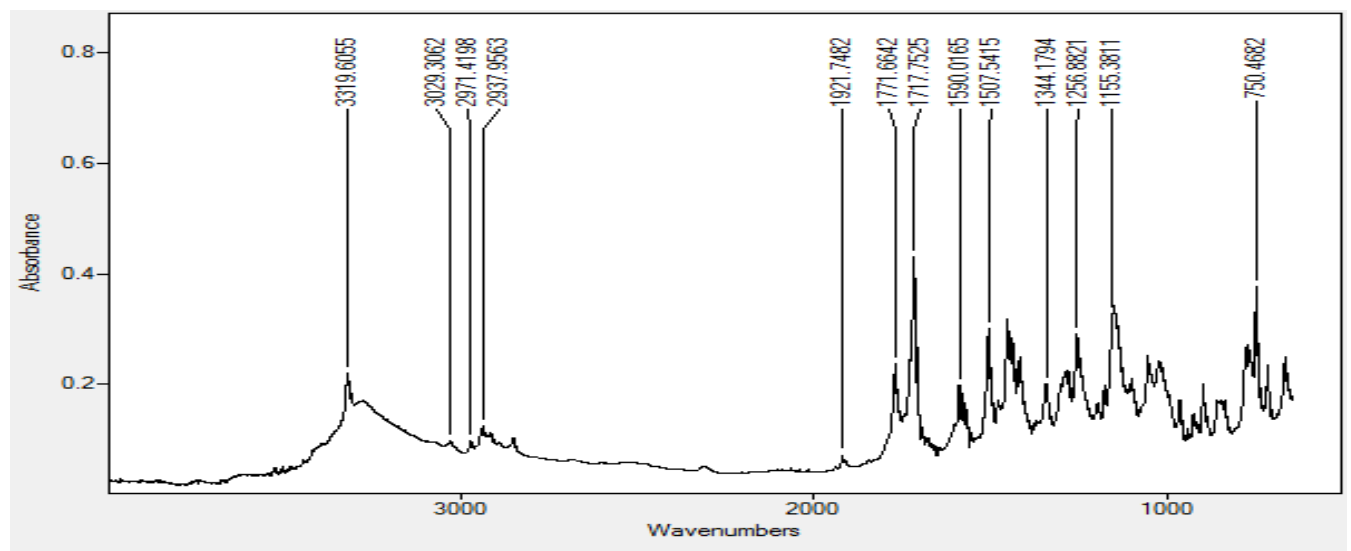

Fig 3: IR spectra of formulation

Table 3: IR Frequency range

\begin{tabular}{|c|c|}
\hline Functional groups & Ranges \\
\hline C-C streching bond & 1921 \\
\hline C=O bond & 1771 \\
\hline C=C bond & 1590 \\
\hline -COOH bond & 1717 \\
\hline -NH bond & 1510 \\
\hline C-Cl bond & 750 \\
\hline
\end{tabular}

c. Melting point of Drug: Melting point of the drug was determined by capillary method and was found to be approximately $152 \pm 0.5^{\circ} \mathrm{C}$. This was within the limits as per literature. This confirms purity of drug substance.

d. Solubility study: Solubility study was performed in water, ethanol, methanol, chloroform.

2. Construction of calibration curve: Calibration curve for aceclofenac drug was determined in PBS (pH 7.4) by UV method.

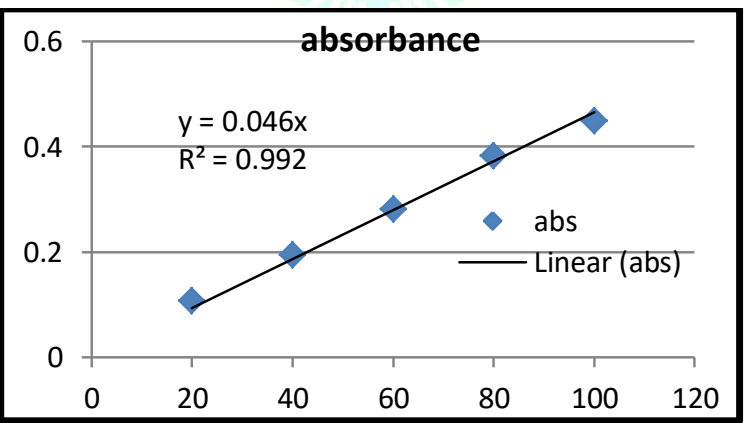

Fig 4: Calibration curve of aceclofenac

Table 4: Absorbance values of Aceclofenac

\begin{tabular}{|c|c|}
\hline Concentration (ug/ml) & Absorbance \\
\hline 20 & 0.107 \\
\hline 40 & 0.194 \\
\hline 60 & 0.282 \\
\hline 80 & 0.383 \\
\hline 100 & 0.450 \\
\hline
\end{tabular}

\section{Drug-Excipients compatibility study}

Compatibility studies of pure drug with superdisintegrants and other excipients were carried out prior to the preparation of tablets. The pure drug was mixed with each excipients in the ratio of 1:1 individually. The drug-excipient mixtures were taken in the vials which was previously washed, cleaned and completely dried in an oven.

Table 5: Drug excipients compatibility studies

\begin{tabular}{|c|c|c|c|}
\hline Sr No & Drug + Excipients & Observation & Result \\
\hline 1 & Drug + Crosscarmellose sodium & White to off white powder & Compatible \\
\hline 2 & Drug + Micro crystalline cellulose & White to off white powder & Compatible \\
\hline 3 & Drug + Lactose & White to off white powder & Compatible \\
\hline 4 & Drug +Magnesium stearate & White to off white powder & Compatible \\
\hline 5 & Drug + Sodium saccharine & White to off white powder & Compatible \\
\hline
\end{tabular}


EVALUATION TEST FOR FAST DISSOLVING TABLET [9-13]

\section{PRE-COMPRESSION PARAMETERS}

Table 6: Precompression evaluation of Aceclofenac mouth dissolving tablets

\begin{tabular}{|c|c|c|c|c|c|}
\hline Formulation & $\begin{array}{c}\text { Angle of } \\
\text { repose( })\end{array}$ & $\begin{array}{c}\text { Bulk density } \\
\text { (g/ml) }\end{array}$ & $\begin{array}{c}\text { Tapped density } \\
\text { (g/ml) }\end{array}$ & $\begin{array}{c}\text { Carr's Index } \\
\text { (\%) }\end{array}$ & $\begin{array}{c}\text { Hausner's } \\
\text { ratio }\end{array}$ \\
\hline F1 & $28.59 \pm 0.27$ & $0.625 \pm 0.023$ & $0.758 \pm 0.017$ & $17.55 \pm 0.21$ & $1.21 \pm 0.03$ \\
\hline F2 & $26.57 \pm 0.35$ & $0.641 \pm 0.016$ & $0.758 \pm 0.023$ & $15.44 \pm 0.14$ & $1.18 \pm 0.02$ \\
\hline F3 & $26.70 \pm 0.28$ & $0.610 \pm 0.028$ & $0.735 \pm 0.028$ & $17.01 \pm 0.19$ & $1.20 \pm 0.04$ \\
\hline F4 & $28.32 \pm 0.24$ & $0.625 \pm 0.017$ & $0.735 \pm 0.007$ & $14.97 \pm 0.07$ & $1.18 \pm 0.06$ \\
\hline F5 & $26.70 \pm 0.18$ & $0.595 \pm 0.029$ & $0.694 \pm 0.009$ & $14.27 \pm 0.08$ & $1.17 \pm 0.05$ \\
\hline F6 & $27.74 \pm 0.30$ & $0.610 \pm 0.024$ & $0.714 \pm 0.020$ & $14.57 \pm 0.16$ & $1.17 \pm 0.04$ \\
\hline F7 & $28.59 \pm 0.29$ & $0.658 \pm 0.014$ & $0.781 \pm 0.024$ & $15.75 \pm 0.13$ & $1.19 \pm 0.02$ \\
\hline F8 & $28.94 \pm 0.17$ & $0.490 \pm 0.025$ & $0.595 \pm 0.017$ & $17.65 \pm 0.09$ & $1.21 \pm 0.03$ \\
\hline F9 & $28.41 \pm 0.21$ & $0.481 \pm 0.018$ & $0.581 \pm 0.008$ & $17.21 \pm 0.24$ & $1.21 \pm 0.05$ \\
\hline
\end{tabular}

\section{Angle of repose}

The angle of repose of the drug powder was in the range of $26.57 \pm 0.35$ to $28.94 \pm 0.17$, which indicates good flow of the drug powder.

\section{Bulk density}

Bulk density of the drug powder was found to be in the range of $\mathrm{g} / \mathrm{ml} 0.481 \pm 0.018$ to $0.658 \pm 0.014 \mathrm{~g} / \mathrm{ml}$.

\section{Tapped density}

Tapped density of the drug powder was found to be in the range of $0.581 \pm 0.008 \mathrm{~g} / \mathrm{ml}$ to $0.781 \pm 0.024 \mathrm{~g} / \mathrm{ml}$.

\section{Carr's compressibility index}

The Carr's index was found to be in the range of $14.27 \pm 0.08 \%$ to $17.65 \pm 0.09 \%$ indicating good flow of the powder blends.

\section{Hausner ratio}

Haunser's ratio was found in the range of $1.17 \pm 0.04$ to $1.21 \pm 0.05$ indicates good flow of the powder blends.

\section{POST COMPRESSION PARAMETERS.}

Table 7: Post compression evaluation of Aceclofenac mouth dissolving tablets

\begin{tabular}{|c|c|c|c|c|c|c|}
\hline $\begin{array}{c}\text { Formula } \\
\text { tion }\end{array}$ & $\begin{array}{l}\text { Thickness } \\
\text { (mm) }\end{array}$ & Diameter (mm) & $\begin{array}{l}\text { Hardness } \\
\left(\mathrm{kg} / \mathrm{cm}^{2}\right)\end{array}$ & $\begin{array}{c}\text { Weight } \\
\text { variation }(\mathrm{mg})\end{array}$ & Friability (\%) & $\begin{array}{c}\text { Drug } \\
\text { content }\end{array}$ \\
\hline F1 & $3.98 \pm 0.06$ & $9.06 \pm 0.05$ & $2.17 \pm 0.29$ & $249.11 \pm 3.15$ & $0.765 \pm 0.020$ & $88 \%$ \\
\hline F2 & $4.06 \pm 0.08$ & $9.04 \pm 0.07$ & $2.17 \pm 0.29$ & $245.78 \pm 2.36$ & $0.748 \pm 0.009$ & $90 \%$ \\
\hline F3 & $4.30 \pm 0.12$ & $9.15 \pm 0.06$ & $2.17 \pm 0.29$ & $242.89 \pm 2.68$ & $0.758 \pm 0.013$ & $95 \%$ \\
\hline F4 & $4.01 \pm 0.05$ & $9.04 \pm 0.03$ & $2.17 \pm 0.29$ & $253.56 \pm 1.17$ & $0.753 \pm 0.012$ & $90 \%$ \\
\hline F5 & $4.19 \pm 0.07$ & $9.14 \pm 0.02$ & $2.17 \pm 0.29$ & $253.78 \pm 1.88$ & $0.772 \pm 0.010$ & $91 \%$ \\
\hline F6 & $4.10 \pm 0.08$ & $9.11 \pm 0.04$ & $2.17 \pm 0.29$ & $252.22 \pm 2.35$ & $0.780 \pm 0.018$ & $92 \%$ \\
\hline F7 & $4.47 \pm 0.05$ & $9.03 \pm 0.03$ & $2.33 \pm 0.29$ & $256.78 \pm 1.58$ & $0.776 \pm 0.013$ & $94 \%$ \\
\hline F8 & $4.33 \pm 0.03$ & $9.11 \pm 0.01$ & $2.17 \pm 0.29$ & $253.44 \pm 2.49$ & $0.571 \pm 0.017$ & $93 \%$ \\
\hline F9 & $4.06 \pm 0.10$ & $9.13 \pm 0.07$ & $2.17 \pm 0.29$ & $251.78 \pm 2.48$ & $0.588 \pm 0.011$ & $90 \%$ \\
\hline
\end{tabular}

\section{DISINTEGRATION TIME:}

Table 8: Disintegration time

\begin{tabular}{|c|c|}
\hline Batch no & Disintegration time (sec) \\
\hline F1 & 78 \\
\hline F2 & 50 \\
\hline F3 & 47 \\
\hline F4 & 67 \\
\hline F5 & 56 \\
\hline F6 & 96 \\
\hline F7 & 85 \\
\hline F8 & 63 \\
\hline F9 & 60 \\
\hline
\end{tabular}




\section{IN VITRO DISSOLUTION STUDIES}

Table 9: In vitro dissolution Graphs (F1-F9)

\begin{tabular}{|c|c|c|c|c|c|c|c|c|c|}
\hline $\begin{array}{c}\text { Time } \\
\text { (mins) }\end{array}$ & F1 & F2 & F3 & F4 & F5 & F6 & F7 & F8 & F9 \\
\hline $\mathbf{0}$ & 0 & 0 & 3 & 1 & 1.5 & 3.2 & 2 & 0 & 0 \\
\hline $\mathbf{5}$ & 10 & 12 & 15 & 12.5 & 20 & 13.2 & 16 & 18.9 & 20 \\
\hline $\mathbf{1 0}$ & 30 & 29 & 31.83 & 27.23 & 25 & 19 & 30 & 30 & 33.5 \\
\hline $\mathbf{1 5}$ & 43.82 & 30 & 36.5 & 33.5 & 29.2 & 27 & 39 & 42.1 & 42.5 \\
\hline $\mathbf{3 0}$ & 46.21 & 57.89 & 46.69 & 40.23 & 39.33 & 30 & 47.19 & 53.22 & 52.89 \\
\hline $\mathbf{4 5}$ & 53.12 & 74.56 & 79.82 & 53.91 & 51.9 & 38 & 53.11 & 72.56 & 68.3 \\
\hline $\mathbf{6 0}$ & 70 & 93 & 94 & 68 & 69.9 & 42 & 69.01 & 91.63 & 83 \\
\hline
\end{tabular}

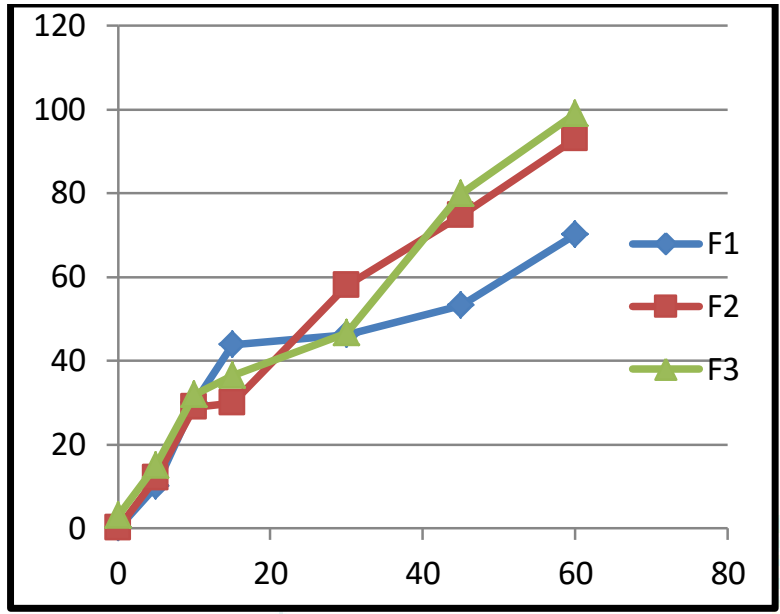

Fig 5: Dissolution graph F1-F3

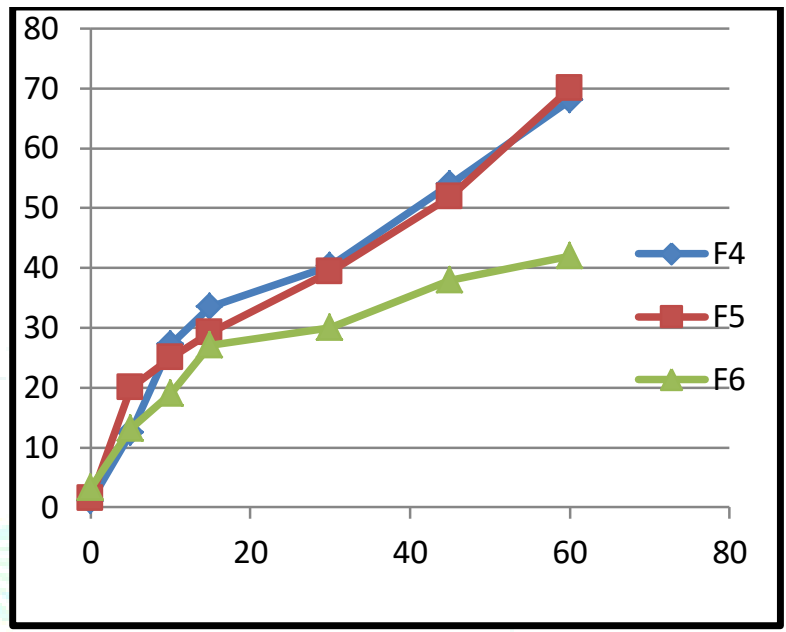

Fig 6: Dissolution graph F4-F6

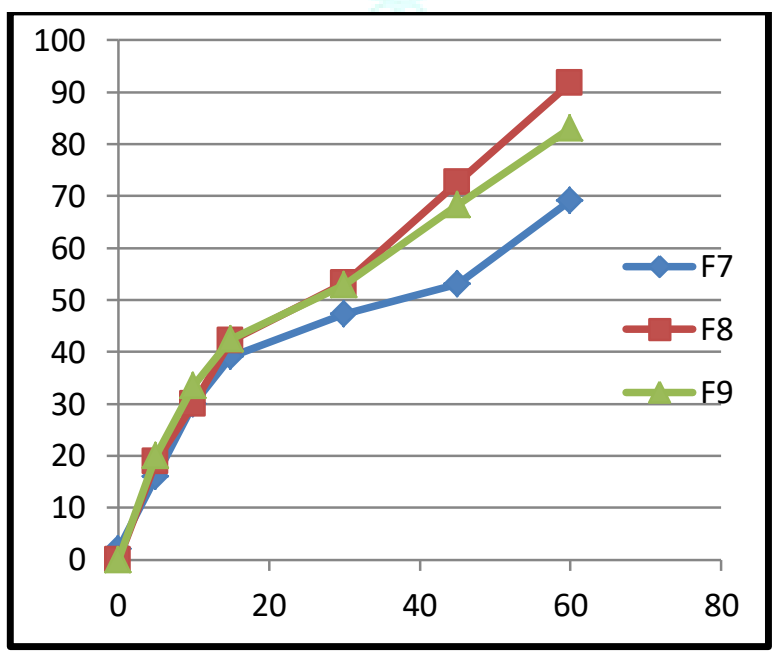

Fig 7: Dissolution graph of F7-F9

RELEASE KINETICS DATA OF OPTIMIZED BATCH:

Table 10: Release Kinetic Model

\begin{tabular}{|c|c|}
\hline Release Kinetic Model & Regression Coefficient (R) $^{\mathbf{2}}$ \\
\hline Zero Order & 0.923 \\
\hline First Order & 0.979 \\
\hline Higuchi Model & 0.994 \\
\hline Hixscon-Crowell Model & 0.972 \\
\hline Koresmeyers- Peppas Model & 0.808 \\
\hline
\end{tabular}




\section{TABLET FORMULATION AND DEVELOPMENT BY USING $3^{2}$ FACTORIAL DESIGNS}

The present study consisted of a three-level two-factorial $\left(3^{2}\right)$ design for experimentation. Statistical experimental design was performed using a software DESIGN EXPERT® version 11 (Stat-Ease Inc., Minneapolis, USA). Response surface graphics were used to show the factor interaction between the considered variables. Selected independent variables studied were the concentration of microcrystaline cellulose and croscarmelose sodium in varying concentrations viz. $\left(\mathrm{X}_{1}\right)$ and $\left(\mathrm{X}_{2}\right)$ respectively. Three factorial levels coded for low, medium and high settings $(-1,0$ and 1 , respectively) were considered for two independent variables. The selected dependent variables investigated were the drug release in $1 \mathrm{hrs}$ (Y1) and disintegration time (Y2). The number of trials required for the study is based on the number of independent variables selected. A total of 9 experimental runs were required for analyzing the interaction of each level on formulation characters and to optimize. $[6,7,8]$

Table 11: Formulation Code

\begin{tabular}{|c|c|c|c|c|}
\hline $\begin{array}{c}\text { Formulation } \\
\text { Code }\end{array}$ & $\mathbf{X}_{1}$ & $\mathbf{X}_{\mathbf{2}}$ & $\begin{array}{c}\text { Microcrystaline } \\
\text { cellulose (X1) }\end{array}$ & $\begin{array}{c}\text { Croscarmelose } \\
\text { sodium (X2) }\end{array}$ \\
\hline F1 & -1 & -1 & 25 & 7.5 \\
\hline F2 & 0 & -1 & 30 & 7.5 \\
\hline F3 & 1 & -1 & 35 & 7.5 \\
\hline F4 & -1 & 0 & 25 & 10 \\
\hline F5 & 0 & 0 & 30 & 10 \\
\hline F6 & 1 & 0 & 35 & 10 \\
\hline F7 & -1 & 1 & 25 & 12.5 \\
\hline F8 & 0 & 1 & 30 & 12.5 \\
\hline F9 & 1 & 1 & 35 & 12.5 \\
\hline
\end{tabular}

\section{Formulation design}

Tablets were made by direct compression method. The various batches were prepared by using 2 super disintegrants namely avicel ph(microcrystalline cellulose), croscarmellose sodium. All the ingredients were passed through 40 \# and 60\# mesh separately. Then the ingredients were weighed and mixed in geometrical order and compressed into tablets to $250 \mathrm{mg}$ by direct compression method by using $8 \mathrm{~mm}$ flat punch.

\section{EXPERIMENTAL DESIGN \& STATISTICAL ANALYSIS}

\section{ANOVA for Linear model}

Response 1: Dissolution

Table 12: Analysis of variance table of dissolution [Partial sum of squares- Type III]

\begin{tabular}{|c|c|c|c|c|c|c|}
\hline Source & Sum of Squares & df & Mean Square & F-value & p-value & \\
\hline Model & 2167.15 & 2 & 1083.57 & 27.68 & $<0.0001$ & significant \\
\hline A-MCC & 373.83 & 1 & 373.83 & 9.55 & 0.0114 & \\
\hline B-S.D & 1793.32 & 1 & 1793.32 & 45.82 & $<0.0001$ & \\
\hline Residual & 391.42 & 10 & 39.14 & & & \\
\hline Lack of Fit & 391.42 & 6 & 65.24 & & & \\
\hline Pure Error & 0.0000 & 4 & 0.0000 & & & \\
\hline Cor Total & 2558.56 & 12 & & & & \\
\hline
\end{tabular}

Factor coding is Coded.

Sum of squares is Type III - Partial

The Model F-value of 27.68 implies the model is significant. There is only a $0.01 \%$ chance that an F-value this large could occur due to noise. P-values less than 0.0500 indicate model terms are significant. In this case A, B are significant model terms. Values greater than 0.1000 indicate the model terms are not significant.

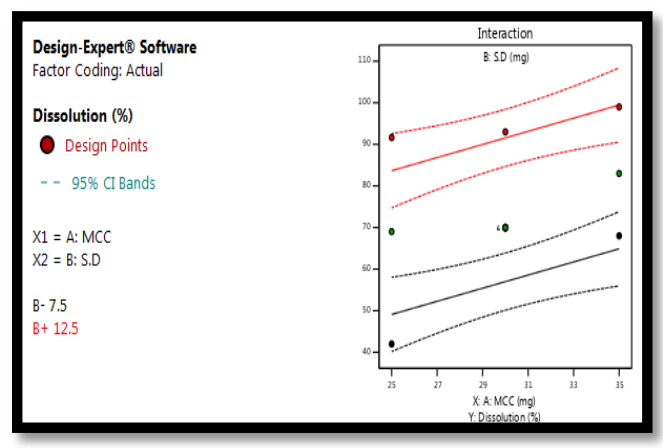

Fig 8: Interaction plot
Design-Expert@ Software

Factor Coding: Actual

Dissolution (\%)

Design points above predicted value

O Design points below predicted value

$\square 99$

$X 1=A: M C C$

$X_{2}=B: S . D$

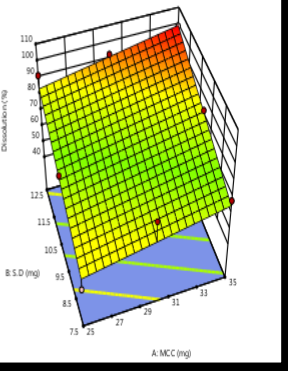

Fig 9: 3D plot 


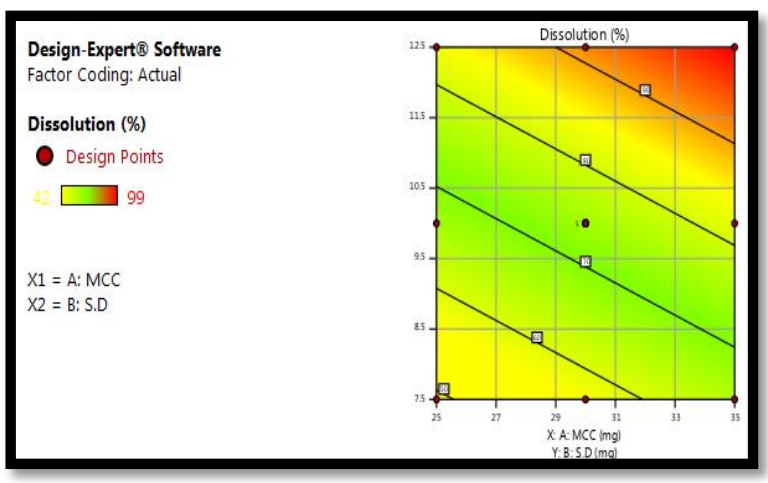

Fig 10: Counter plot

Response 2: Disintigration time

Table 13: Analysis of variance

\begin{tabular}{|c|c|c|c|c|c|c|}
\hline Source & Sum of Squares & df & Mean Square & F-value & p-value & \\
\hline Model & 216.67 & 2 & 108.33 & 112.37 & $<0.0001$ & significant \\
\hline A-MCC & 66.67 & 1 & 66.67 & 69.15 & $<0.0001$ & \\
\hline B-CCS & 150.00 & 1 & 150.00 & 155.59 & $<0.0001$ & \\
\hline Residual & 9.64 & 10 & 0.9641 & & & \\
\hline Lack of Fit & 9.64 & 6 & 1.61 & & & \\
\hline Pure Error & 0.0000 & 4 & 0.0000 & & & \\
\hline Cor Total & 226.31 & 12 & & & & \\
\hline
\end{tabular}

Factor coding is Coded.

Sum of squares is Type III - Partial

The Model F-value of 112.37 implies the model is significant. There is only a $0.01 \%$ chance that an F-value this large could occur due to noise.
P-values less than 0.0500 indicate model terms are significant. In this case A and B are significant model terms. Values greater than 0.1000 indicate the model terms are not significant. If there are many insignificant model terms (not counting those required to support hierarchy), model reduction may improve your model.

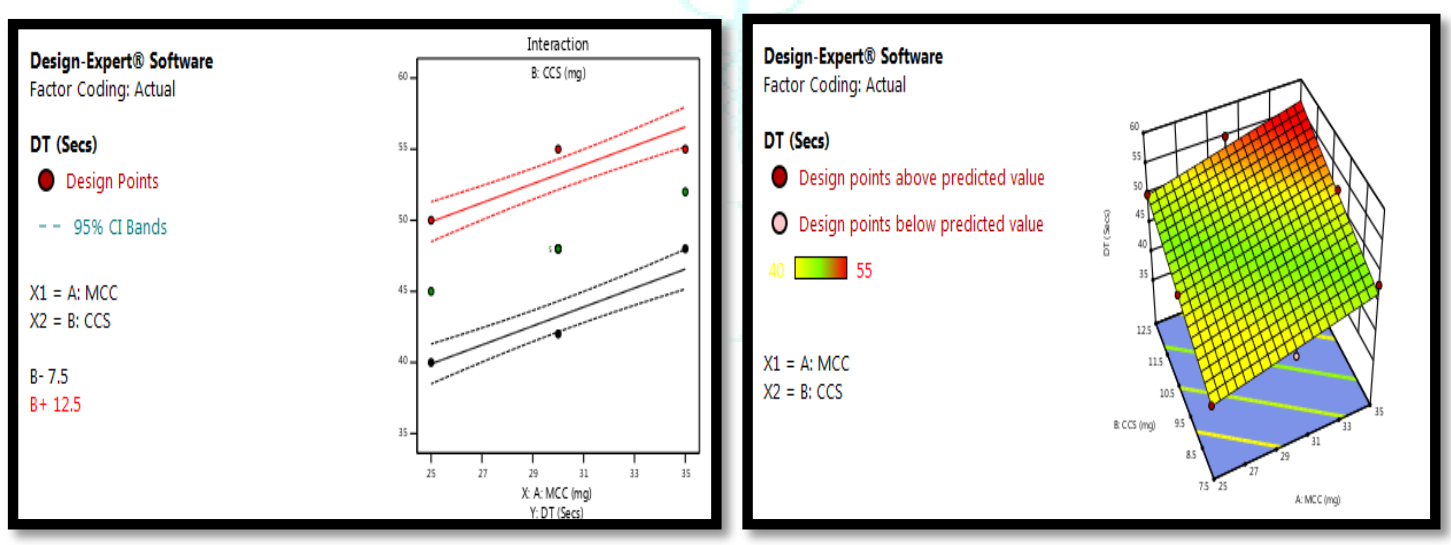

Fig 11: Interaction Plot

Fig 12: 3D Plot

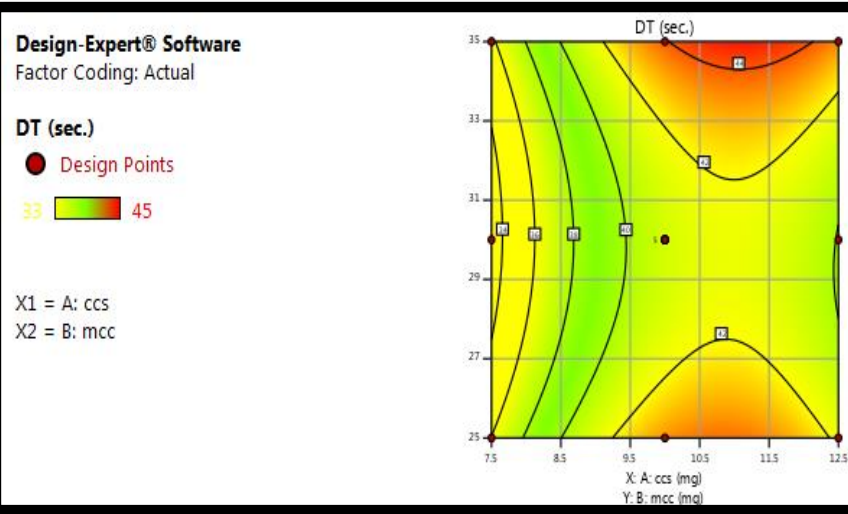

Fig 13: Contour plot 


\section{CONCLUSION}

1. Aceclofenac Mouth dissolving tablets were prepared by using Cross carmellose sodium and Micro crystalline cellulose as superdisintgrants, Lactose as Diluent, Magnesium stearate as flowing aid and sodium saccharin as sweetner.

2. Aceclofenac MDT was prepared for fast release and quick action for inflammatory conditions.

3. The optimized batch followed Higuchi model for release kinetics.

4. In conclusion, it is suggested that Aceclofenac MDT with crosscarmellose sodium and avicel ph can be a better option in inflammatory conditions.

5. It was concluded that fast disintegrating tablets of Aceclofenac can be successfully prepared using selected superdisitegrants in order to improve disintegration/dissolution of the drug in oral cavity and hence better patient compliance and effective therapy.

\section{CONFLICTS OF INTERESTS:}

The authors declare that there is no conflict of interests regarding the publication of this paper.

\section{AUTHORS CONTRIBUTION:}

We declare that this work was done by the authors named in this article and all liabilities pertaining to claims relating to the content of this article will be borne by the authors. $\mathrm{Mr}$ Shravan Yadav collected the data, and analysed the data. Dr. (Mr.) Asish dev proof-read the whole manuscript, and suggested the necessary changes, and helped in designing manuscript.

\section{REFERENCES}

1. Kulkarni Ajit Vamanrao, RC Hariprasanna.,.V.K Mohan S, Manmataya, Kulkarni Upendra, Design and development of Aceclofenac fast dissolving tablets by different techniques: The Pharma Innovation Journal (2015); 4(3): 30-38.

2. Saha Suman, Design and optimization of immediate release tablet of Salbutamol sulphate by direct compression technique: Journal of Applied Pharmaceutical Research Volume 6, Issue 3, Year of Publication (2018): 13 - 19

3. Singh Shailendra Solanki, Dahima Rashmi, Formulation and evaluation of Aceclofenac mouth-dissolving tablet: J. Adv. Pharm. Tech. Res (2011); 2.

4. Yong CS, Oh YK, Lee KH, Park SM, Park YJ, Gil YS et al., Trials of clear Aceclofenac- loaded soft capsules with accelerated oral absorption in human subjects: Int J Pharm (2005); 302: 78-83.

5. Marshall K, Lachman N, Liberman HA., The theory and practice of industrial pharmacy: 3rd Ed,Varghese Publishing House, Mumbai, 1987; 66- 69.

6. Gunda Raghavendra kumar, Jujjuru naga suresh kumar, Formulation development and evaluation of Amisulpride fast dissolving tablets: FABAD j. pharm. sci. (2018); 43 (2): 105115.

7. P.V. Swamy, S.M. Shahidulla, S.B. Shirsand, S.N. Hiremath and Md. Younus Ali, Orodispersible tablets of Carbamazepine prepared by direct compression method using 32 full factorial design: Dhaka Univ. J. Pharm. Sci. (2008); 7(1): 1-5.

8. Nandare Dinesh S., Mandlik Satish K., Khiste Sachin K. and Mohite Yogesh D., Formulation and optimization of mouth dissolving tablets of Olanzapine by using 32 factorial design: Research J. Pharm. and Tech. (2011); 4(8): 1265-1268.

9. Schiermeier Simone, Schmidt Peter Christian, Fast dispersible Ibuprofen tablets: European Journal of Pharmaceutical Sciences (2002); 15: 295-305.

10. Al-khattawi Ali \& Mohammed Afzal R, Challenges and emerging solutions in the development of compressed orally disintegrating tablets: Expert Opin. Drug Discov. (2014); 9 (10):1109-1120.

11. Swain Ranjit Prasad \& Subudhi Bharat Bhusan, Effect of semicrystalline copolymers in solid dispersions of pioglitazone hydrochloride: In vitro-in vivo correlation, Drug Development and Industrial Pharmacy (2019); 45(5): 1-43.

12. Sarfraz R. M., Khan H. U., Mahmood A., Ahmad M., Maheen S. and Sher M., Formulation and evaluation of mouth disintegrating tablets of Atenolol and Atorvastatin: Indian J Pharm Sci. (2015); 77(1): 83-90.

13. Y. X. Bi, H. Sunada, Y. Yonezawa, and K. Danjo, Evaluation of rapidly disintegrating tablets prepared by a direct compression method: Drug Development and Industrial Pharmacy (1999); 25(5): 571-581. 